\title{
PERLUNYA PERDA TENTANG RETRIBUSI PERPANJANGAN IZIN MEMPEKERJAKAN TENAGA KERJA ASING DI TENGAH LIBERALISASI TENAGA KERJA MASYARAKAT EKONOMI ASEAN 2015
}

(The Importance of Local Regulation Regarding Retribution Fees on Renewal License for Hiring Foreign Workers in The Liberalization of Foreign Workers among ASEAN Community 2015)

\author{
Budi S.P. Nababan \\ Kantor Wilayah Kementerian Hukum dan HAM Sumatera Utara \\ Email: budinababan.bn@gmail.com
}

Naskah diterima: 21 Mei 2014; revisi: 25 Agustus 2014; disetujui: 27 Agustus 2014

\begin{abstract}
Abstrak
Salah satu pilar utama ASEAN Vision 2020 adalah ASEAN Economic Community yang akan dipercepat di tahun 2015 sehingga akan menyebabkan terjadinya liberalisasi tenaga kerja di kawasan Asia Tenggara. Adapun yang menjadi permasalahan dalam tulisan ini adalah mengapa diperlukan Perda tentang Retribusi Perpanjangan Izin Mempekerjakan Tenaga Kerja Asing di tengah liberalisasi tenaga kerja ASEAN Community 2015. Dengan menggunakan penelitian yuridis normatif diketahui bahwa Perda tentang Retribusi Perpanjangan Izin Mempekerjakan Tenaga Kerja Asing diperlukan agar daerah bisa memungut retribusi terhadap perpanjangan izin bekerja para TKA (kecuali Instansi Pemerintah, BadanBadan Internasional dan Perwakilan Negara Asing), sebab tanpa adanya pengaturan (regeling) tidak ada dasar yuridis bagi Pemerintah Daerah untuk memungutnya. Mengingat tingginya potensi kehadiran TKA, penulis menyarankan agar segera dibentuk Ranperda tentang Retribusi Perpanjang Izin Mempekerjakan Tenaga Kerja Asing bagi daerah yang belum memiliki Perda tersebut dan menjadikannya skala prioritas untuk dibahas dan ditetapkan menjadi perda.

Kata Kunci: retribusi, tenaga kerja asing, peraturan daerah

\section{Abstract}

One of main pillars of the ASEAN Vision 2020 is the ASEAN Economic Community that will be accelerated in 2015 that will lead to the liberalization of foreign workers in Southeast Asia. The main problem in this paper is why is Local Regulation on Retribution Fees Renewal License for Hiring Foreign important in the liberalization of foreign workers ASEAN Community 2015. By using normative research method acknowledge that The Local Regulation on Retribution Fees Renewal License For Hiring Foreign needed to be so the local government can collect fees on extension of work permit of foreign workers (except Government employees, International Agencies and Foreign Representative), because without regulation (regelling) there is no legal basis for local governments to collect it. Regarding on high potential for the presence of foreign workers, as authors suggest to boost formation of Local Regulation on Retribution Fees Renewal License For Hiring Foreign workers Draft immediately for local government who has not have these regulations yet and make this as priority to discuss and enact into regulation.
\end{abstract}

Keywords: retribution, foreign workers, local regulation 


\section{A. Pendahuluan}

Liberalisasi dalam perekonomian ASEAN sesungguhnya tidak terlepas dari perkembangan globalisasi internasional. Perkembangan globalisasi internasional menuntut negaranegara ASEAN untuk lebih kompetitif lagi ${ }^{1}$. Dalam Kamus Besar Bahasa Indonesia disebutkan globalisasi adalah proses masuknya ke ruang lingkup dunia.

Globalisasi secara luas telah membuka perekonomian dunia dalam skala yang hampir tidak terbatas. Globalisasi juga menuntut ASEAN menciptakan integrasi regional di Asia Tenggara. Integrasi regional di Asia Tenggara ini dikenal dengan ASEAN Vision 2020. Salah satu pilar utama ASEAN Vision 2020 adalah Masyarakat Ekonomi ASEAN 2015 (ASEAN Economic Community 2015). ASEAN Economic Community 2015 merupakan ide integrasi ekonomi negara-negara anggota ASEAN, yang menjadi komitmen bersama untuk dipercepat pada tahun 2015 untuk enam negara terkaya ASEAN salah satunya Indonesia dan kemudian dilanjutkan pada tahun 2020 oleh negara Kamboja, Myanmar, Laos dan Vietnam.

Kemudian pada tanggal 20 November 2007 dalam deklarasi ASEAN di Singapura sepuluh negara anggota ASEAN sepakat untuk menandatangani kesepakatan yang berisi cetak biru (blueprint) ASEAN Economic Community 2015. Dalam blueprint ASEAN Economic Community 2015 disepakati lima elemen penting dalam integrasi perekonomian ASEAN salah satunya adalah liberalisasi arus tenaga kerja. Pada liberalisasi arus tenaga kerja terjadi pembebasan arus tenaga kerja ahli terbatas sampai tahun 2020, selebihnya keseluruhan tenaga kerja (baik yang ahli maupun kurang ahli) bisa melakukan migrasi dengan bebas, tanpa memerlukan visa kerja khusus dan perizinan yang menyulitkan banyak tenaga kerja dari negara berkembang di ASEAN, misalnya Indonesia untuk mendokumentasikan data dirinya secara legal.

Di Indonesia kehadiran tenaga kerja asing (selanjutnya disingkat dengan TKA) sebagai suatu kebutuhan sekaligus tantangan yang tidak dapat dihindari lagi, karena negara kita membutuhkan TKA pada berbagai sektor. Pergerakan tenaga kerja antar negara ini akan mempengaruhi situasi keterampilan dan pengetahuan tenaga kerja di Indonesia. Kehadiran TKA dalam perekonomian nasional suatu negara mampu menciptakan kompetisi yang bermuara pada efisiensi dan meningkatkan daya saing perekonomian. Sedangkan secara filosofis dan spirit globalisasi, penggunaan TKA pada negara berkembang dimaksudkan untuk alih pengetahuan (transfer of knowledge) dan alih teknologi (transfer of technology) ${ }^{2}$.

Menurut Staf Ahli Menteri Bidang Hubungan Antar Lembaga Kementerian Tenaga Kerja dan Transmigrasi, saat ini komposisi yang telah ditetapkan oleh Pemerintah adalah sebanyak 
49\% maksimal diisi oleh TKA, sisanya 51\% diisi oleh $\mathrm{TKI}^{3}$. Tujuan pengkomposisian tersebut adalah untuk memenuhi kebutuhan tenaga kerja terampil dan professional dibidang tertentu yang belum dapat diisi oleh TKI serta mempercepat proses pembangunan nasional dengan jalan mempercepat alih ilmu pengetahuan dan tekonologi dan meningkatkan investasi asing sebagai penunjang pembangunan di Indonesia ${ }^{4}$.

Hadirnya TKA di negara kita akan berdampak bagi pendapatan asli daerah ${ }^{5}$. Namun sayangnya, belum banyak daerah yang menyadarinya. Hal ini terbukti dengan belum banyak daerah yang memiliki Peraturan Daerah tentang Retribusi Perpanjangan Izin Mempekerjakan Tenaga Kerja Asing (selanjutnya disebut dengan Perda Retribusi Perpanjangan IMTA) sebagai dasar hukum dalam pemungutan retribusi perpanjangan IMTA. Sesungguhnya pemberi kerja yang akan memperpanjang izin mempekerjakan tenaga kerja asing (kecuali Instansi Pemerintah, BadanBadan Internasional dan Perwakilan Negara Asing) akan dikenai retribusi perpanjangan IMTA yang ditetapkan berdasarkan tingkat penggunaan jasa yang tidak akan melebihi tarif PNBP perpanjangan IMTA yang berlaku pada kementerian yang menyelenggarakan urusan pemerintahan di bidang ketenagakerjaan. Namun untuk dapat memungut retribusi tersebut terlebih dahulu harus ada Perda sebagai conditio sine quanon bagi pemungutan retribusi perpanjangan IMTA.

Berkaitan dengan uraian diatas menjadi penting untuk dibahas bagaimana situasi TKA di Indonesia? Mengapa diperlukan Perda tentang Retribusi Perpanjangan Izin Mempekerjakan Tenaga Kerja Asing penting di tengah liberalisasi tenaga kerja ASEAN Community 2015?

\section{B. Metode Penelitian}

Dilihat dari tipologi penelitian, maka tulisan ini merupakan penelitian yuridis normatif (yuridis normative research). Penelitian yuridis normatif disebut juga dengan penelitian perpustakaan atau studi dokumen ${ }^{6}$ karena itu penulis lebih banyak melakukan penelitian terhadap data yang telah ada yang diperoleh dari perpustakaan maupun internet.

Adapun spesifikasi penelitian yang digunakan dalam tulisan ini adalah deskriptif. Soerjono Soekanto menyatakan bahwa penelitian berbentuk deskriptif bertujuan menggambarkan realitas obyek yang diteliti, dalam rangka menemukan hubungan diantara dua gejala, dengan memberikan gambaran secara sistematis, mengenai peraturan hukum dan fakta-fakta sebagai pelaksanaan peraturan perundang-undangan tersebut di lapangan.

\footnotetext{
HR Abdussalam, Hukum Ketenagakerjaan, (Jakarta: Restu Agung, 2008), hlm. 322.

$5 \quad$ Pendapatan Asli Daerah merupakan pendapatan Daerah yang bersumber dari hasil pajak daerah, hasil retribusi daerah, hasil pengelolaan kekayaan Daerah yang dipisahkan, dan lain-lain Pendapatan Asli Daerah yang sah, yang bertujuan untuk memberikan keleluasaan kepada Daerah dalam menggali pendanaan dalam pelaksanaan otonomi daerah sebagai perwujudan asas desentralisasi. Penjelasan Umum Undang-Undang Nomor 33 Tahun 2004 tentang Perimbangan Keuangan Antara Pemerintah Pusat dan Daerah.

6 Bambang Waluyo, Penelitian Hukum Dalam Praktek, (Jakarta: Sinar Grafika, 1996), hlm. 13-14.

7 Soerjono Soekanto, Pengantar Penelitian Hukum, (Jakarta: UI-Press, 1984), hlm. 96.
} 
Berkaitan dengan sumber penelitian", sumber penelitian dalam tulisan ini berasal dari publikasi tentang hukum yang merupakan dokumen-dokumen resmi yang berupa peraturan perundang-undangan serta dokumen yang tidak resmi yang berupa buku-buku teks hukum dan jurnal hukum. Di samping itu, tulisan ini juga menggunakan bahan-bahan non hukum yang dipandang mempunyai relevansi berupa hasil penelitian tentang ekonomi yang termuat dalam skripsi dan jurnal serta berita tentang ekonomi yang termuat dalam surat kabar elektronik.

\section{Pembahasan}

\section{Situasi TKA Di Tanah Air}

Sebagaimana yang telah penulis kemukakan sebelumnya bahwa komposisi penggunaan TKA di tanah air telah ditetapkan oleh Pemerintah adalah sebanyak 49\% maksimal diisi oleh TKA, sisanya $51 \%$ diisi oleh TKI, hal ini untuk menjamin dan memberi kesempatan kerja yang layak bagi warga negara Indonesia diberbagai lapangan dan level pekerjaan. Pengkomposisian tenaga kerja di tanah air merupakan salah satu bentuk campur tangan Pemerintah dalam bidang ketenagakerjaan. Campur tangan ini dimaksudkan untuk terciptanya hubungan ketenagakerjaan yang adil, karenajika hubungan antara pekerja dan pemberi kerja sangat berbeda secara sosial ekonomi diserahkan sepenuhnya pada para pihak, maka tujuan untuk menciptakan keadilan dalam hubungan ketenagakerjaan akan sulit tercapai, karena pihak yang kuat akan selalu ingin menguasai yang lemah ${ }^{9}$.

Berkaitan dengan campur tangan dibidang ketenagakerjaan, dalam mempekerjakan TKA Pemerintah telah memberi sejumlah ramburambu yang harus diperhatikan oleh pemberi kerja antara lain:

a. Pemberi kerja yang mempekerjakan TKA wajib memiliki izin tertulis dari Menteri atau pejabatyangditunjuk, kecualibagiperwakilan negara asing yang mempergunakan TKA sebagai pegawai diplomatik dan konsuler tidak wajib memiliki izin;

b. Pemberi kerja orang perseorangan dilarang mempekerjakan TKA;

c. Pemberi kerja yang menggunakan tenaga kerja asing harus memiliki rencana penggunaan TKA yang disahkan oleh Menteri; dan

d. TKA dapat dipekerjakan di Indonesia hanya dalam hubungan kerja untuk jabatan tertentu dan waktu tertentu.

Oleh karena itu TKA yang bekerja di Indonesia harus mematuhi segala ketentuan hukum ketenagakerjaan Indonesia. Sampai dengan sekarang pengaturan hukum tentang 
TKA masih tersebar dalam berbagai peraturan perundang-undangan. Beberapa peraturan perundang-undangan tersebut yang masih relevan antara lain:

a. Undang-Undang Nomor 13 Tahun 2003 tentang Ketenagakerjaan, khususnya Bab VIII menyangkut Penggunaan TKA;

b. Peraturan Pemerintah Nomor 65 Tahun 2012 tentang Jenis dan Tarif Atas Penerimaan Negara Bukan Pajak Yang Berlaku Pada Kementerian Tenaga Kerja dan Transmigrasi;

c. Keputusan Presiden Nomor 75 Tahun 1995 tentang Penggunaan Tenaga Kerja Warga Negara Asing Pendatang;

d. Keputusan Menteri Tenaga Kerja dan Transmigrasi Nomor 223/Men/2003 tentang Jabatan-Jabatan Di Lembaga Pendidikan Yang Dikecualikan Dari Kewajiban Membayar Kompensasi;

e. Keputusan Menteri Tenaga Kerja dan Transmigrasi Nomor 228/Men/2003 tentang Tata Cara Pengesahan Rencana Penggunaan Tenaga Kerja Asing;

f. Keputusan Menteri Tenaga Kerja dan Transmigrasi Nomor 20/Men/III/2004 tentang Tata Cara Memperoleh Izin Mempekerjakan Tenaga Kerja Asing;

g. Keputusan Menteri Tenaga Kerja dan Transmigrasi Nomor 21/Men/IV/2004 tentang Penggunaan Tenaga Kerja Asing Sebagai Pemandu Nyanyi;

h. Peraturan Menteri Tenaga Kerja dan Transmigrasi Nomor 07/Men/III/2006 jo Nomor 15/Men/2006 tentang Penyederhanaan Prosedur Penerbitan Izin Mempekerjakan Tenaga Kerja Asing;

i. Peraturan Menteri Tenaga Kerja dan Transmigrasi Nomor 02/Men/XII/2004 tentang Pelaksanaan Program Jaminan Sosial Tenaga Kerja Bagi Tenaga Kerja Asing; dan j. Peraturan Menteri Tenaga Kerja dan Transmigrasi Nomor 02/Men/III/2008 tentang Tata Cara Penggunaan Tenaga Kerja Asing.

k. Selain diatur dalam peraturan perundangundangan di bidang ketenagakerjaan, penggunaan TKA juga harus memperhatikan peraturan lain seperti Undang-Undang Nomor 6 Tahun 2011 tentang Keimigrasian, Undang-Undang Nomor 39 Tahun 2009 tentang Kawasan Ekonomi Khusus, dan bahkan peraturan daerah dimana TKA akan bekerja.

Jika diperhatikan berbagai peraturan perundang-undangan yang ada tersebut akan terlihat mekanisme dan prosedur yang ketat dalam mempekerjakan TKA yang dimulai dengan seleksi dan prosedur perizinan hingga pengawasan. Karena itu diperlukan peraturan perundang-undangan yang mendukung terhadap kebutuhan TKA dalam kaitannya mendukung pelaksanaan ASEAN Economic Community. Hal ini dirasa penting karena jika peraturan perundang-undangan kita belum sejalan, bukan tidak mungkin nantinya TKA yang sudah ada di dalam negeri akan angkat kaki.

Dalam kapasitas untuk dapat mewujudkan keikutsertaan Indonesia dalam kancah ASEAN Economic Community, tentunya hal ini bukanlah hal yang mudah. Perlu persiapan dan kematangan baik dari segi peraturan perundang-undangan, sumber daya manusia yang berkecimpung, serta infrastruktur yang mendukung.

Dalam hal pembentukan peraturan perundang-undangan di Indonesia yang mendukung terhadap terlaksananya ASEAN Economic Community, pembentukan produk hukum tersebut harus sejalan dengan arah pembangunan hukum nasional sebagaimana 
tertuang dalam Undang-Undang Nomor 17 Tahun 2007 tentang Rencana Pembangunan Jangka Panjang Nasional ${ }^{10}$. Untuk itu harus diwaspadai berbagai modus tekanan ataupun godaan dari pihak asing dalam pembentukan peraturan perundang-undangan ${ }^{11}$ dalam rangka mendukung ASEAN Economic Community atau mengandung prinsip-prinsip yang sama, atau paling tidak memiliki dasar nilai filosofis dan sosiologis yang mendukung dengan prinsipprinsip dalam ASEAN Economic Community. Jangan sampai pembentukan peraturan perundang-undangan untuk mendukung ASEAN Economic Community melenceng dari arah pembangunan hukum nasional seperti yang telah tertuang dalam Undang-Undang Nomor 17 Tahun 2007 tersebut.

Menurut ketentuan peraturan perundangundangan, TKA adalah warga negara asing pemegang visa dengan maksud bekerja di wilayah Indonesia ${ }^{12}$. Defenisi dalam tersebut sedikit berbeda dengan apa yang disampaikan oleh Budiono, yang mengatakan TKA adalah tiap orang bukan warga negara Indonesia yang mampu melakukan pekerjaan, baik di dalam maupun di luar hubungan kerja, guna menghasilkan jasa atau barang untuk memenuhi kebutuhan masyarakat ${ }^{13}$.

TKA telah menjadi bagian dari tenaga kerja yang ada di Indonesia. Sebagai gambaran mengenai situasi TKA di tanah air diketahui bahwa: ${ }^{14}$

a. Pada akhir tahun 2005 sebanyak 50.903 TKA bekerja di Indonesia, jumlah ini meningkat dibandingkan pada tahun 2004 yang berjumlah 43.091 orang. Sebagian besar TKA tersebut bekerja di sektor industri yaitu 13.212 orang $(25,95 \%)$, sektor perdagangan sebanyak 9.817 orang $(19,28 \%)$ dan paling sedikit di sektor pertanian sebanyak 1.103 orang $(2,17 \%)$.

b. Selama tahun 2013, tercatat sebanyak 68.957 orang TKA yang bekerja di Indonesia didominasi sektor perdagangan dan jasa sebanyak36.913orang, sektorindustri24.029 dan sektor pertanian sebanyak 8.015 orang. Dari level jabatan, TKA tetap didominasi level profesional, advisor/consultant, manager, direksi, supervisor, teknisi dan komisaris. Namun jumlah ini menurun bila dibandingkan dengan jumlah TKA yang masuk dan bekerja di Indonesia pada tahun 2012 yang mencapai 72.427 orang dan tahun 2011 sebanyak 77.307 orang.

c. Seperti tahun-tahun sebelumnya para TKA yang berasal Tiongkok, Jepang dan Korea Selatan, India dan Malaysia masih tetap mendominasi jumlah total TKA yang bekerja di Indonesia. Kehadiran TKA dari 5 negara tersebut

10 Akhmad Aulawi, "Arah Pembangunan Hukum Dalam Menghadapi ASEAN Economic Community 2015", Jurnal RechtsVinding Online, hlm. 2.

11 Reza Fikri Febriansyah, "Pengaruh Internasional Dalam Proses Pembentukan Undang-Undang Di Indonesia", Jurnal Legislasi Indonesia, (Vol. 10 Nomor 03, September 2013), hlm. 241.

12 Pasal 1 angka 13 Undang-Undang Nomor 13 Tahun 2003 tentang Ketenagakerjaan.

13 Abdul Khakim, Dasar-Dasar Hukum Ketenagakerjaan Indonesia, (Bandung: Citra Aditya Bakti, 2009), hlm. 27.

14 Tenaga Kerja Asing Harus Patuhi Norma Dan Budaya Kerja Indonesia, http://www.jpnn.com/ read/2014/05/12/233983/Tenaga-Kerja-Asing-Harus-Patuhi-Norma-dan-Budaya-Kerja-Indonesia. Pekerja Asing Serbu Indonesia, http://disnakertransduk.jatimprov.go.id/ketenagakerjaan/223-pekerja-asing-serbuindonesia. Tahun 2013 Jumlah Pekerja Asing Di Indonesia Menurun, http://www.m.tribunnews.com, (diakses 19Juli 2014). 
memang terus mendonimasi TKA dari tahun ke tahun. Bahkan pada tahun 2013 jumlah TKA dari Tiongkok jumlahnya mencapai 14.371 orang, Jepang 11.081 orang, dan Korea Selatan 9.075 orang, sedangkan TKA dari India 6.047 orang, dan Malaysia 4.962 orang. Adapun pekerja asing dari Eropa berasal dari Inggris (36\%), Prancis (20\%), Belanda (16\%) dan Jerman (10\%).

Berdasarkan gambaran tersebut, kita bisa melihat sebelum berlakunya ASEAN Economic Community 2015 saja sudah cukup banyak TKA di negara kita, apalagi dengan berlakunya ASEAN Economic Community 2015. Sebab adanya ASEAN Community 2015 maka TKA bisa bermigrasi dengan bebas tanpa memerlukan visa kerja khusus dan perizinan yang menyulitkan ${ }^{15}$. Migrasi ini tentunya akan meningkatkan jumlah TKA di tanah air. Banyaknya TKA di tanah air sebenarnya merupakan salah satu pembawa devisa bagi negara sebab berdasarkan ketentuan Undang-Undang Nomor 36 Tahun 2008 tentang Perubahan Keempat Atas UndangUndang Nomor 7 Tahun 1983 tentang Pajak Penghasilan, TKA yang bekerja di Indonesia juga termasuk subjek pajak karena TKA mendapatkan suatu penghasilan atas apa yang telah dia kerjakan selama di Indonesia, sehingga sudah sewajarnya juga dikenakan pajak penghasilan yang dibebankan kepada perusahaan/badan tempat TKA tersebut bekerja dan mendapatkan penghasilan. Selain itu bagi Pemerintah Daerah kehadiran TKA merupakan tambang emas sebab terhadap perpanjangan izin bekerja TKA dapat dikenakan retribusi.

\section{Perlunya Perda Tentang Retribusi Perpanjangan IMTA Di Tengah Liberalisasi Tenaga Kerja ASEAN Community 2015}

Pada prinsipnya berbagai peraturan perundang-undangan telah menyatakan bahwa Retribusi Perpanjangan IMTA merupakan kewenangan yang dimiliki oleh Pemerintah Daerah, meskipun masih secara sumir. Hal ini dapat ditelusuri dalam:

a. Undang-Undang Dasar Negara Republik Indonesia Tahun 1945, telah menegaskan bahwa daerah berhak untuk menetapkan perda ${ }^{16}$;

b. Undang-Undang Nomor 32 Tahun 2004 tentang Pemerintahan Daerah, telah menegaskan bahwa salah satu tugas dan wewenang kepala daerah adalah mengajukan Ranperda kemudian Ranperda tersebut dibahas dengan DPRD sebagai salah satu bentuk tugas dan wewenang DPRD, setelah itu akan ditetapkan oleh kepala daerah setelah mendapat persetujuan bersama DPRD ${ }^{17}$;

15 Masalah perizinan merupakan salah satu yang krusial menyangkut dua sisi kepentingan yaitu, kepentingan pemerintah untuk melakukan regulasi terhadap kegiatan tertentu yang dilakukan oleh masyarakat agar sesuai dengan perencanaan, kondisi dan kebutuhan pemerintah daerah, di sisi lain adalah kepentingan kebutuhan masyarakat untuk memperoleh kepastian hukum dalam melakukan usaha dan kegiatan yang mempunyai efek di bidang sosial, ekonomi, politik dan sebagainya. Penulis melihat yang menjadi penyebab sulitnya perizinan di Indonesia antara lain: prosedur pengurusan izin yang berbelit-belit dan terlalu banyak instansi yang terlibat; biaya yang terlalu tinggi; persyaratan yang tidak relevan; waktu penyelesaian izin yang terlalu lama; dan kinerja pelayanan yang sangat rendah.

16 Lihat Pasal 18 ayat (6) Undang-Undang Dasar Negara Republik Indonesia Tahun 1945.

17 Lihat Pasal 25 huruf c, Pasal 42 ayat (1) huruf a, dan Pasal 136 ayat (1) Undang-Undang Nomor 32 Tahun 2004 tentang Pemerintahan Daerah. 
c. Undang-Undang Nomor 28 Tahun 2009 tentang Pajak Daerah dan Retribusi Daerah, telah menegaskan bahwa jenis retribusi daerah dapat ditambah sepanjang memenuhi kriteria yang telah ditetapkan ditetapkan dengan Peraturan Pemerintah ${ }^{18}$;

d. Peraturan Pemerintah Nomor 38 Tahun 2007 tentang Pembagian Urusan Pemerintahan Antara Pemerintah, Pemerintahan Daerah Provinsi, dan Pemerintahan Daerah Kabupaten/Kota, menyebutkan jika salah satu urusan wajib pemerintahan daerah adalah bidang ketenagakerjaan ${ }^{19}$. Kemudian dalam lampiran Peraturan Pemerintah ini bidang ketenagakerjaan dibagi atas sub bidang, dan setiap sub bidang dibagi lagi dalam sub-sub bidang, salah satu subsub bidang tersebut adalah penerbitan perpanjangan IMTA.

Kewenangan yang dimiliki oleh Pemerintah Daerah baru secara tegas dinyatakan dalam Peraturan Pemerintah Nomor 97 Tahun 2012 tentang Retribusi Pengendalian Lalu Lintas dan Retribusi Perpanjangan Izin Mempekerjakan Tenaga Kerja Asing yang telah diundangkan dalam Lembaran Negara Republik Indonesia Tahun 2012 Nomor 216, Tambahan Lembaran Negara Republik Indonesia Nomor 5358 pada tanggal 30 Oktober 2012. Dalam peraturan pemerintah ini, pemberian perpanjangan izin mempekerjakan tenaga kerja asing dikenakan retribusi ${ }^{20}$, dimana subjek retribusinya adalah pemberi kerja tenaga kerja asing ${ }^{21}$ dengan besaran tarif retribusi yang ditetapkan dengan Perda ${ }^{22}$. Kewenangan ini mulai diberlakukan sejak tanggal 1 Januari $2013^{23}$, hal ini untuk memberikan kesempatan kepada daerah mempersiapkan kebijakan daerah dan hal-hal lain yang diperlukan dalam rangka pelaksanaan pemungutan retribusi perpanjangan IMTA. Maka berdasarkan sejumlah ketentuan tersebut jelas bahwa Peraturan Pemerintah Nomor 97 Tahun 2012 telah mendelegasikan kewenangan retribusi perpanjangan IMTA kepada daerah.

ASEAN Economic Community 2015 akan diarahkan kepada pembentukan sebuah integrasi ekonomi kawasan dengan mengurangi biaya transaksi perdagangan, memperbaiki fasilitas perdagangan dan bisnis, serta meningkatkan daya saing sektor usaha mikro, kecil dan menengah. Pemberlakuan ASEAN Economic Community 2015 bertujuan untuk menciptakan pasar tunggal dan basis produksi yang stabil, makmur, berdaya saing tinggi, dan secara ekonomi terintegrasi dengan regulasi efektif untuk perdagangan dan investasi, yang di dalamnya terdapat arus bebas lalu lintas barang, jasa, investasi, dan modal serta difasilitasinya kebebasan pergerakan pelaku usaha dan tenaga kerja.

Implementasi ASEAN Economic Community 2015 akan berfokus pada dua belas sektor 
prioritas, yang terdiri atas tujuh sektor barang (industri pertanian, peralatan elektonik, otomotif, perikanan, industri berbasis karet, industri berbasis kayu, dan tekstil) dan lima sektor jasa (transportasi udara, pelayanan kesehatan, pariwisata, logistik, dan industri teknologi informasi atau e-ASEAN). Apabila peluang ini dioptimalkan, maka Indonesia akan mendapatkan keuntungan ekonomi yang lebih besar dibandingkan negara-negara lainnya. Tidak tertutup kemungkinan para investor (dalam dan/atau luar negeri) akan menanamkan modalnya di negara kita, sehingga TKA akan bermigrasi dengan bebas akibat kebutuhan TKA di berbagai sektor ${ }^{24}$. Migrasi TKA tersebut sesuai dengan blueprint ASEAN Economic Community 2015 yang sudah ditandatangani tahun 2009, yang berisi kesepakatan pembebasan arus tenaga kerja ahli terbatas sampai tahun 2020. Selebihnya keseluruhan tenaga kerja (baik yang ahli maupun kurang ahli) bisa melakukan migrasi dengan bebas, tanpa memerlukan visa kerja khusus dan perizinan yang menyulitkan banyak tenaga kerja dari negara berkembang di ASEAN.

Meskipun di tahun 2013 jumlah TKA menurun dibandingkan di tahun 2012 bahkan di tahun 2011 sebagaimana yang telah diuraikan sebelumnya, namun penulis meyakini bahwa jumlah TKA akan lebih meningkat lagi seiring dengan berlakunya ASEAN Economic Community 2015. TKA tersebut akan tersebar di daerahdaerah terutama di daerah yang memiliki daya saing tinggi seperti di DKI Jakarta, Jawa Timur, Jawa Barat, Kalimantan Timur, Kepulauan Riau, Jawa Tengah dan Banten.

Semakin banyaknya TKA yang akan masuk ke daerah, Pemerintah Daerah harus berani mengambil langkah pengaturannya, dimana upaya ini dilakukan untuk mengantisipasi berbagai hal yang mungkin saja bisa terjadi seperti opini negatif yang timbul di masyarakat bahwa TKA hanya mengeruk keuntungan bagi mereka sendiri, TKA tidak akan berpengaruh pada pendapatan daerah. Hal ini merupakan suatu kekeliruan sebab para TKA yang izinnya diperpanjang akan dikenakan retribusi, namun karena banyaknya daerah yang belum memiliki perda maka pembayaran izinnya langsung kepada Pemerintah Pusat ${ }^{25}$ sehingga terkesan TKA tidak memberikan kontribusi sama sekali.

Berlakunya ASEAN Economic Community 2015 bukan berarti terhadap TKA tidak dapat dipungut retribusi perpanjangan IMTA, sebab yang menjadi agenda dalam ASEAN Economic Community 2015 adalah TKA tidak lagi memerlukan visa kerja khusus dan perizinan yang menyulitkan seperti yang berlaku selama ini, sehingga Pemerintah Daerah masih bisa memungut retribusi yang memang benar-benar

$24 \quad$ Pusat Data dan Informasi Ketenagakerjaan Badan Penelitian Pengembangan dan Informasi Departemen Tenaga Kerja dan Transmigrasi Republik Indonesia, Situasi Tenaga Kerja Dan Kesempatan Tenaga Kerja Di Indonesia, Jakarta: 2006.

25 Berkaitan dengan hal ini, Kepala Seksi Penempatan Tenaga Kerja Luar Negeri Dinas Sosial dan Tenaga Kerja Kota Medan pernah mengatakan kebanyakan TKA membayar biaya perpanjangan izin dana pengembangan keterampilan dan keahlian (DPKK) langsung kepada Pemerintah Pusat, sedangkan ke kas Pemerintah Kota tidak ada. Berdasarkan DPKK, biaya perpanjangan izin TKA sebesar USD 1.200 per tahun. Seharusnya ketika masa izin habis maka TKA tersebut memperpanjang izin ke dinas tenaga kerja di tempatnya bekerja. Tenaga Kerja Asing Tak Punya Kontribusi. Budi S.P. Nababan, "Mendorong Lahirnya Peraturan Daerah Tentang Retribusi Perpanjangan Izin Mempekerjakan Tenaga Kerja Asing Di Kota Medan”, Jurnal Legislasi Indonesia, (Vol. 11 Nomor 01, Maret 2014), hlm. 51-52. 
ada dan diakui peraturan perundang-undangan yang masih berlaku. Oleh karenanya Pemerintah Daerah perlu memiliki pemahaman yang baik ${ }^{26}$ atas situasi yang dihadapi di daerahberkaitan dengan retribusi daerah.

Sebagai bagian dari negara hukum, tentunya segala kebijakan dan tindakan Pemerintah Daerah harus berlandaskan pada aturan hukum. Hal ini menjadi syarat mutlak untuk memungut pajak maupun retribusi, karena pemungutan pajak dan retribusi tanpa aturan hukum sama saja dengan perampokan. Di Amerika Serikat dikenal dengan "Taxation Without Representation Is Robbery" sedangkan di Inggris dikenal dengan "No Taxation Without Representation". Kedua dalil tersebut memiliki esensi yang sama dengan Pasal 23A Undang-Undang Dasar Negara Republik Indonesia Tahun 1945 yang menyebutkan bahwa "Pajak dan pungutan lain yang bersifat memaksa untuk keperluan Negara harus diatur dengan undang-undang". Sehingga berdasarkan ketentuan Pasal 23A Konstitusi ini tanpa adanya pengaturan (regeling) tidak ada dasar yuridis bagi Pemerintah Daerah untuk melakukan pungutan pajak atau retribusi apa pun.

Karena itu Pemerintah Daerah perlu menetapkan Perda tentang Retribusi Perpanjangan IMTA sebagai instrumen hukum dalam melakukan pungutan retribusi perpanjangan IMTA, selain itu sebagaimana yang telah diuraikan sebelumnya bahwa retribusi perpanjangan IMTA merupakan salah satu kewenangan yang dimiliki oleh Pemerintah Daerah. Dalam menyusun Perda tentang Retribusi Perpanjangan IMTA, harus harus diingat bahwa: dasar hukumnya adalah Pasal 18 ayat (6) Undang-Undang Dasar Negara Republik Indonesia Tahun 1945, Undang-Undang tentang Pembentukan Daerah, Undang-Undang Nomor 32 Tahun 2004 tentang Pemerintahan Daerah sebagaimana telah diubah beberapa kali terakhir dengan Undang-Undang Nomor 12 Tahun $2008^{27}$, serta peraturan perundangundangan di bawah Undang-Undang Dasar Negara Republik Indonesia Tahun 1945 yang memerintahkan secara langsung pembentukan peraturan perundang-undangan ${ }^{28}$, yaitu Peraturan Pemerintah Nomor 97 Tahun 2012 tentang Retribusi Pengendalian Lalu Lintas dan Retribusi Perpanjangan Izin Mempekerjakan Tenaga Kerja Asing.

Retribusi perpanjangan IMTA adalah pungutan atas pemberian perpanjangan izin mempekerjakan tenaga kerja asing kepada pemberi kerja tenaga kerja asing ${ }^{29}$, sedangkan perpanjangan IMTA adalah izin yang diberikan oleh gubernur atau bupati/walikota atau pejabat yang ditunjuk kepada pemberi kerja tenaga kerja asing sesuai dengan ketentuan peraturan perundang-undangan ${ }^{30}$. Retribusi perpanjangan IMTA sebenarnya merupakan pengalihan kewenangan dari PNBP Pemerintah Pusat menjadi retribusi Pemerintah Daerah.

26 Lihat lebih lanjut David Kairupan, Aspek Hukum Penanaman Modal Asing Di Indonesia, (Jakarta: Kencana Prenada Media Group, 2013), hlm. 7.

27 Lihat butir 39 Lampiran II Undang-Undang Nomor 12 Tahun 2011 tentang Pembentukan Peraturan Perundangundangan.

Lihat butir 40 Lampiran II, Ibid.

29 Lihat Pasal 1 angka 3 Peraturan Pemerintah Nomor 97 Tahun 2012 tentang Retribusi Pengendalian Lalu Lintas dan Retribusi Perpanjangan Izin Mempekerjakan Tenaga Kerja Asing.

30 Lihat Pasal 1 angka 4, Ibid. 
Karena itu pembentukan Perda tentang retribusi perpanjangan IMTA dapat dipastikan tidak akan menghambat ASEAN Economic Community 2015, mengingat retribusi perpanjangan IMTA sebelumnya merupakan PNBP yang kemudian dilimpahkan kepada daerah untuk dipungut sebagai retribusi. Pemungutan retribusi perpanjangan IMTA dilaksanakan oleh Pemerintah Provinsi untuk perpanjangan IMTA yang lokasi kerjanya lintas kabupaten/kota dalam provinsi yang bersangkutan dan Pemerintah Kabupaten/Kota untuk perpanjangan IMTA yang lokasi kerjanya dalam kabupaten/kota yang bersangkutan. Selain itu Peraturan Pemerintah Nomor 97 Tahun 2012 telah menegaskan bahwa tarif retribusi perpanjangan IMTA yang akan ditetapkan berdasarkan tingkat penggunaan jasa tidak akan melebihi tarif PNBP perpanjangan IMTA yang berlaku pada Kementerian yang menyelenggarakan urusan pemerintahan di bidang ketenagakerjaan ${ }^{31}$.

Perda tentang Retribusi Perpanjangan IMTA tidak sama dengan regulasi yang akan diterapkan Negara Singapura ${ }^{32}$ sebab perda tentang retribusi perpanjangan IMTA bukanlah untuk merintangi pergerakan arus TKA, sedangkan regulasi yang akan diterapkan Negara Singapura untuk membatasi jumlah tenaga kerja atau imigran asing yang kian meningkat dalam beberapa tahun terakhir melalui kenaikan retribusi yang tinggi. Bagi negara kita retribusi perpanjangan IMTA dapat meningkatkan PAD dimana penerimaan retribusi ini digunakan untuk mendanai penerbitan dokumen izin, pengawasan di lapangan, penegakan hukum, penatausahaan, biaya dampak negatif dari perpanjangan IMTA, dan kegiatan pengembangan keahlian dan keterampilan tenaga kerja lokal ${ }^{33}$.

Beberapa Pemerintah Daerah telah menyadari potensi kehadiran TKA di wilayahnya dengan membentuk Perda tentang Retribusi Perpanjangan IMTA, seperti Kabupaten Purwakarta (Perda Nomor 12 Tahun 2013 yang mulai dilaksanakan pada tanggal 1 Juni 2013), Provinsi Kalimantan Selatan (Perda Nomor 10 Tahun 2013 yang mulai berlaku sejak tanggal 28 Oktober 2013), Kota Batam (Perda Nomor 4 Tahun 2013 yang mulai diberlakukan sejak tanggal 11 April 2013), Kabupaten Badung (Nomor 20 Tahun 2013 yang mulai berlaku sejak tanggal 1 Januari 2014), Kota Depok (Perda Nomor 2 Tahun 2013 yang mulai berlaku sejak tanggal 14 Mei 2013), dan Provinsi Nusa Tenggara Barat (Perda Nomor 10 Tahun 2013 yang mulai berlaku sejak tanggal 13 Desember 2013).

Adapun bagi daerah-daerah yang belum memiliki Perda tentang Retribusi Perpanjangan IMTA, Pemerintah Daerahnya dituntut untuk bergelut dengan waktu yang tersisa untuk membentuk perda tersebut, sebab era perdagangan bebas di negara-negara ASEAN tinggal hitungan waktu. Tidak kurang dari 2 tahun pelaksanaan ASEAN Economic Community akan segera dilaksanakan, tepatnya tanggal

31 Lihat Pasal 15 Peraturan Pemerintah Nomor 97 Tahun 2012 tentang Retribusi Pengendalian Lalu Lintas dan Retribusi Perpanjangan Izin Mempekerjakan Tenaga Kerja Asing.

Singapura Akan Batasi Tenaga Kerja Asing, http://internasional.kompas.com/read/2013/02/26/05083392/ Singapura.Akan.Batasi.Tenaga.Kerja.Asing, (diakses 19 Mei 2014).

33 Lihat Pasal 16 ayat (1) Peraturan Pemerintah Nomor 97 Tahun 2012 tentang Retribusi Pengendalian Lalu Lintas dan Retribusi Perpanjangan Izin Mempekerjakan Tenaga Kerja Asing. 
31 Desember 2015. Jangan sampai di tengah berlangsungnya ASEAN Economic Community, Pemerintah Daerah tidak bisa memungut retribusi perpanjangan IMTA. Hal ini sangat disayangkan mengingat saat ini saja kehadiran TKA di tanah air sudah cukup tinggi apalagi dengan diberlakukannya ASEAN Economic Community 2015.

\section{Penutup}

Berdasarkan pembahasan sebelumnya disimpulkan bahwa, berlakunya ASEAN Community 2015 akan menyebabkan TKA semakin tinggi kehadirannya di negara kita sebab TKA akan bermigrasi dengan bebas tanpa visa kerja khusus dan perizinan yang menyulitkan. Terhadap TKA tersebut masih bisa dikenakan retribusi perpanjangkan IMTA (kecuali yang bekerja di Instansi Pemerintah, Badan-Badan Internasional dan Perwakilan Negara Asing) sesuai dengan Peraturan Pemerintah Nomor 97 Tahun 2012 tentang Retribusi Pengendalian Lalu Lintas dan Retribusi Perpanjangan Izin Mempekerjakan Tenaga Kerja Asing. Retribusi perpanjangkan IMTA merupakan retribusi yang baru ditetapkan oleh Pemerintah Pusat untuk diberlakukan Pemerintah Daerah sejak tanggal 1 Januari 2013. Agar daerah bisa memungutnya perlu adanya Perda tentang Retribusi Perpanjangan IMTA sesuai dengan amanat Pasal 23A Undang-Undang Dasar Negara Republik Indonesia Tahun 1945, tanpa adanya perda tersebut tidak ada dasaryuridis bagi Pemerintah Daerah untuk memungut retribusi tersebut. Oleh karena itu sangat diperlukan Perda tentang Retribusi Perpanjangan IMTA di tengah liberalisasi tenaga kerja ASEAN Community 2015, namun sayangnya hanya beberapa Pemerintah Daerah saja yang telah membentuk Perda tentang Retribusi Perpanjangan IMTA.
Mengingat tingginya kehadiran TKA di tanah air sejalan pula dengan pelaksanaan ASEAN Economic Community 2015 yang tinggal hitungan waktu, penulis menyarankan bagi daerah yang belum memiliki Perda tentang Retribusi Perpanjangan IMTA agar segera menyusun draftnya dan mencantumkan Ranperda tentang Retribusi Perpanjangan IMTA dalam Program Legislasi Daerah sehingga menjadi skala prioritas untuk dibahas dan ditetapkan menjadi perda. Karena itu sangat dibutuhkan keseriusan Pemerintah Daerah dan DPRD dalam mewujudkan kehadiran Perda tentang Retribusi Perpanjangan IMTA, sebab pada akhirnya Perda tentang Retribusi Perpanjangan IMTA ini nantinya akan digunakan Pemerintah Daerah sebagai instrumen hukum di daerah dalam melakukan pungutan retribusi perpanjangan IMTA. Retribusi perpanjangan IMTA ini nantinya untuk mendanai penerbitan dokumen izin, pengawasan di lapangan, penegakan hukum, penatausahaan, biaya dampak negatif dari perpanjangan IMTA, dan kegiatan pengembangan keahlian dan keterampilan tenaga kerja lokal.

\section{DAFTAR PUSTAKA}

\section{Buku}

Abdussalam, HR, Hukum Ketenagakerjaan, (Jakarta: Restu Agung, 2008).

Badan Pembinaan Hukum Nasional, Kementerian Hukum dan HAM Republik Indonesia, Kompendium Hukum Bidang Ketenagakerjaan, (Jakarta: 2012).

Departemen Perdagangan Republik Indonesia, Menuju ASEAN Economic Community 2015, (Jakarta: 2010).

Djani D, Triansyah, ASEAN Selayang Pandang, (Jakarta: Direktorat Jenderal Kerjasama ASEAN Departemen Luar Negeri Republik Indonesia, 2007).

Khakim, Abdul, Dasar-Dasar Hukum Ketenagakerjaan Indonesia, (Bandung: Citra Aditya Bakti, 2009). 
Kairupan, David, Aspek Hukum Penanaman Modal Asing Di Indonesia, (Jakarta: Kencana Prenada Media Group, 2013).

Marzuki, Peter Mahmud, Penelitian Hukum, (Jakarta: Kencana, 2010).

Pusat Data dan Informasi Ketenagakerjaan, Badan Penelitian Pengembangan dan Informasi, Departemen Tenaga Kerja dan Transmigrasi Republik Indonesia, Situasi Tenaga Kerja Dan Kesempatan Tenaga Kerja Di Indonesia, (Jakarta: 2006).

Soekanto, Soerjono, Pengantar Penelitian Hukum, (Jakarta: UI-Press, 1984).

Waluyo, Bambang, Penelitian Hukum Dalam Praktek, (Jakarta: Sinar Grafika, 1996).

Wijoyo, Wisnu Harto Adi, Determinan Migrasi Internasional: Migrasi Netto Studi Kasus ASEAN Dan Gravitasi Migrasi Keluar Dari Indonesia, (Depok: Skripsi Fakultas Ekonomi Universitas Indonesia, 2011).

\section{Makalah/ Artikel/ Prosiding/ Hasil Penelitian}

Aulawi, Akhmad, "Arah Pembangunan Hukum Dalam Menghadapi ASEAN Economic Community 2015", Jurnal RechtsVinding Online.

Febriansyah, Reza Fikri, "Pengaruh Internasional Dalam Proses Pembentukan Undang-Undang Di Indonesia", Jurnal Legislasi Indonesia, (Vol. 10, Nomor 03, September 2013).

Nababan, Budi S.P, "Mendorong Lahirnya Peraturan Daerah Tentang Retribusi Perpanjangan Izin Mempekerjakan Tenaga Kerja Asing Di Kota Medan", Jurnal Legislasi Indonesia, (Vol. 11 Nomor 01, Maret 2014).

Tim Perbankan dan Enquiry Point, "Tenaga Kerja Asing Pada Perbankan Nasional", Buletin Hukum Perbankan dan Kebanksentralan, (Vol. 5 Nomor 3, Desember 2007).

\section{Internet}

Pemerintah Akan Atur Tenaga Kerja Asing, http:// www.m.tempo.co/read/news/2013/11/06 /090527514/ (diakses 27 Januari 2014).
Tahun 2013 Jumlah Pekerja Asing Di Indonesia Menurun. http://www.m.tribunnews.com (diakses 20 Januari 2014).

Tenaga Kerja Asing Harus Patuhi Norma Dan Budaya Kerja Indonesia, http://www.jpnn. com/read/2014/05/12/233983/Tenaga-KerjaAsing-Harus-Patuhi-Norma-dan-Budaya-KerjaIndonesia (diakses 19 Mei 2014).

Pekerja Asing Serbu Indonesia, http://disnakertrans duk.jatimprov.go.id/ketenagakerjaan/223pekerja-asing-serbu-indonesia (diakses 19 Mei 2014).

Singapura Akan Batasi Tenaga Kerja Asing, http:// internasional.kompas.com/read/2013/02/26 /05083392/Singapura.Akan.Batasi.Tenaga.Kerja. Asing (diakses 19 Mei 2014).

Menakar Kesiapan Indonesia Hadapi AEC 2015, http://news.liputan6.com/read/566007/ menakar-kesiapan-indonesia-hadapi-aec-2015 (diakses 19 Juli 2014).

\section{Peraturan Perundang-undangan}

Undang-Undang Dasar Negara Republik Indonesia Tahun 1945.

Undang-Undang Nomor 13 Tahun 2003 tentang Ketenagakerjaan.

Undang-Undang Nomor 32 Tahun 2004 tentang Pemerintahan Daerah.

Undang-Undang Nomor 28 Tahun 2009 tentang Pajak Daerah dan Retribusi Daerah.

Undang-Undang Nomor 12 Tahun 2011 tentang Pembentukan Peraturan Perundang-undangan.

Peraturan Pemerintah Nomor 38 Tahun 2007 tentang Pembagian Urusan Pemerintahan Antara Pemerintah, Pemerintahan Daerah Provinsi, dan Pemerintahan Daerah Kabupaten/Kota.

Peraturan Pemerintah Nomor 97 Tahun 2012 tentang Retribusi Pengendalian Lalu Lintas dan Retribusi Perpanjangan Izin Mempekerjakan Tenaga Kerja Asing. 